\title{
The Dynamic Relationships Between Balance of Trade and Economic growth in Tanzania
}

\author{
Lucas P. Mwisila ${ }^{1^{*}} \quad$ Hassani Z. Msumi ${ }^{2} \quad$ Jumanne A. Karume ${ }^{3}$ \\ 1.Department of Science and Management, Dar es Salaam Maritime Institute \\ P.O.Box 6727 Dar Es Salaam \\ 2.Department of Marine Engineering, Dar es Salaam Maritime Institute \\ P.O.Box 6727 Dar Es Salaam \\ 3.Department of Maritime Transport, Dar es Salaam Maritime Institute \\ P.O.Box 6727 Dar Es Salaam
}

\begin{abstract}
This paper analysed the dynamic relationships and causal effects between balance of trade and the Gross Domestic Product (GDPT). In regard of time series data used in this study, Tanzania has been in trade balance deficit for 23 years. On the other hand the Gross Domestic Product has been substantially increasing annually. The developed GDPT model was stationary at level and at first difference. Likewise, the system of three equations was formulated with the variables GDPT, Exports and Imports and the system was found to have combination of both I(1) and I(0). It was found from this study that the coefficient for Error Correction Term (ECT) for GDPT Model was insignificant which mean that the explanatory variables Exports and Imports were weak enabler or no effect over GDPT convergence in the long run equilibrium. However, the coefficient for ECT has negative sign which mean that the GDPT model is capable of converging in the long run normally in the current year, after having random shocks in the previous year. One of the reasons for no convergence is the speed of adjustment or annual correction rate of 2.77 percent is very low and would take 36 years to converge in the long run equilibrium. Moreover, only the Exports variable at L2D was significant and has causal relationships contributing 27.92 percent over GDPT in the short run, nevertheless, this contribution did not endure in the long run. On the other hand Imports variable was not significant and no causal effects over GDPT in the long run and short run which is quite good as imports have no direct relationship to GDPT. Either failure of Exports to endure in the long run, means that the economic policies on Imports had been little strategic in boosting local industrial productions in the short run which could enhance export demand-Led growth for International markets and local demand-Led growth for local markets and hence reduce unnecessary imports. Nevertheless, Tanzania of current is geared towards industrialized economy which in turn will reverse the situations found in this study in the near future. The researcher recommends that research and development in what to be imported, exported, strategic policies, promotions and motivations to local producers and consumers be made.
\end{abstract}

Keywords: Exports(X), Imports (M) and Gross Domestic Product (GDPT)

DOI: $10.7176 / \mathrm{JESD} / 12-10-08$

Publication date:May $31^{\text {st }} 2021$

\section{Introduction}

Balance of Trade (BoT) is a trade-off between Exports and Imports in dollars values. If exports and imports are equal the BoT could be zero. However, BoT at the time when business closes; normally annually had never been zero. The BoT for some countries is surplus meaning that exports are greater than imports and for others is deficit meaning that exports are less than imports. Tanzania for more than 23 years from 1995 to 2017 had been having a trade deficit balance (World Bank, 2018). According to Imimole (2017) citing Wu (2000) and Olamade and Oni (2016), the trade deficit should occur as a short term intervention to allow adjustments in local industrial productions and in meeting necessary gaps for material and consumable goods needed in local markets. The long persistence of trade deficit has negative spill over effects to economic growth of a country as it is capable of triggering the increase in local interest rates, rapid depreciation in local currency and reducing living standard. Tanzania of recent has done various economic reforms in various sectors fostering for industrialised economy gearing to sustainable economic growth. That being the case policy maker needs to be aware of the dynamic relationships between balance of trade and economic growth in Tanzania. Tanzania should have strategic policies to ensure that Imports are those that in the short run support the local industrialization growth and in the long run improve the entire economy of Tanzania.

This study analysed the dynamic relationships between balance of trade and economic growth in Tanzania. The dynamics relationship comprises analysis on relationship between the Gross Domestic Product (GDPT) representing the Economic growth of Tanzania as a respondent and the balance of trade comprised Exports and Imports as explanatory variables. Also the study analyses the causal relationship among the variables in the GDPT model. The GDPT model was developed for the purpose of bridging the gap that observed by the researcher. It was found that very little is known in regard of the dynamic relationships between balance of trade and economic 
growth in Tanzania. The findings will help to improve macroeconomic policies in regard to investment, production, operations consumptions and broaden the understanding to policy maker, managers, community and the stakeholders. This study covers a period from 1995 to 2017; the annual import and export values in dollars were from WITS (2018) and the annual GDP values in dollars were from World Bank (2018).

In the manufacturing sector today, human capital is still essential for most factories to carry out a variety of manual operations, in spite of the rapid advancement of automation technology and robotics. Futuristic vision of "unmanned manufacturing" (Deen 1993) is forbiddingly expensive, because all its hardware components need to be computer controlled so as to freely communicate with each other; and yet, most of the outcomes are not promising (Sun \& Venuvinod 2001). By and large, factories equipped with relatively simple machinery controls will require continuous attendance of human operators; for examples, textile mills, leather products, and medical appliances. With limited capital investments in production equipment, the main budget of their fixed costs lies on the workforce size (Techawiboonwong et al. 2006).

With regard to cost-effectiveness, labour planning always opts for the minimum amount of workers needed to deal with the daily operations, as well as the probable rate of disturbance (Lim et al. 2008). The workforce disturbance is often ascribed to absenteeism and turnover, which may result in considerable loss of productivity for any labour-intensive division (Easton \& Goodale 2002). Buffering with redundant skilled workers (Molleman \& Slomp 1999) or relief workers (Redding 2004) might be a direct solution to absenteeism; however, the rising labour cost must be justifiable due to the fact that underutilisation of labour during low demand seasons is considered a waste of resources. Absenteeism is the measure of unplanned absences from workplace due to some reasons like personal emergency, accident, illness, etc. Turnover occurs when an active worker resigns from the company of his own accord, thus leaving a vacant post until a replacement is found. If such disturbance has caused a large number of tasks become unattended and overdue, the company is then vulnerable to overtime cost, shrunk capacity and productivity, extra queuing time, lost business income, etc. In order to prevent these deteriorative effects, optimising the number of workers can be helpful. As a fundamental branch of knowledge in manufacturing business, workforce management will never fall behind the times. Therefore, it is worth an attempt to incorporate a novel methodology, such as HMS, into the state of the art of workforce sizing.

\section{Review of Literature}

Several studies to analyse the relationship of exports, imports and economic growth have been done globally. The finding done by Al-Khulaifi (2013) on exports and imports long run relationships in Qatar revealed that; the variables were cointegrated of order one I(1), variables have long run relationships and had unidirectional causality from imports to exports. The long run causality relationships imply that macroeconomic policies have been effective for long run equilibrium converges of exports and imports. Likewise, Bakari and Krit (2017) investigates the nexus between exports, imports and economic growth in Mauritania found that GDP, exports and imports were stationary when first differenced I(1). The model revealed long run relationship where exports have positive effects to GDP and imports have negative effects to GDP. There is unidirectional causality between imports to GDP, no causality relationship between exports and GDP and concluded that the economy was unstable as productions were hampered by weather conditions and droughts which led to more imports of food. Those were among the reasons; Mauritania made a new economic policy to encourage investment for export products to achieve better economic growth. Moreover, Zestos and Michelis (2004) investigates export, import and GDP growth: causal relations in six European Union Countries found that the variables were cointegrated of order one I(1). The variables have long run relationships and a bidirectional causality relationship is from exports and import to GDP for all countries except the Netherlands for which weaker evidence exists in from GDP to exports and imports. The bidirectional causality relationships imply that macroeconomic policies have been effective in promoting the key sectors of their economies. The policies can effectively be implemented using strategies such as elasticity approach, absorption approach, monetary approach and structural adjustments approach on exports and imports of goods and services.

The Gross Domestic Product (GDP) in dollar value for Tanzania has been increasing; According to World Bank (2018), GDP increased substantially from 5.255 dollars in 1995, 10.186 dollars in 2000, 16.93 dollars in 2005, 31.408 dollars in 2010, 45.623 dollars in 2015 and 52.09 dollars in 2017. The GDP for Tanzania increased gradually despite of having trade deficit which reduces to some extent the GDP dollar value; but the increase in GDP came from other absorption factors such as personal consumption expenditure $(\mathrm{C})$, gross private domestic investment (I) and Government consumption expenditure $(\mathrm{G})$

Imports for Tanzania in the International trade as shown in Figure 2.1 have been higher than exports since 1995 to 2017 resulting to trade deficit balance for 23 years consecutively (WITS, 2018). By average since 1995 the trade deficit was higher than exports in 2015 imports were at its climax resulting into climax for trade deficit. The imports in the next two consecutive years 2016 and 2017 dropped while exports increase resulting to fall in trade deficit. The fall in imports and increase in exports resulted into fall in trade deficit which imply effective implementation of macroeconomic policies. The increase in imports strategically should be for the short run of which in a long run should improve export production and substitute of foreign consumption by local products. 
However, in promoting exports Felipe and Lim (2005) said that a successful and sustained growth require embedded system of both exports and domestic demands-Led Growth. For emerging markets countries extra efforts are needed particularly for in restructuring exports policies in pricing, nonprice competition, necessary technology, skilled human resource and infrastructures. Moreover, the domestic demand meaning the local markets should be promoted in order to reduce unnecessary foreign consumption products. In this case apart of improving local products to compete with foreign products the policy maker should inspire the local consumers to use the local products.

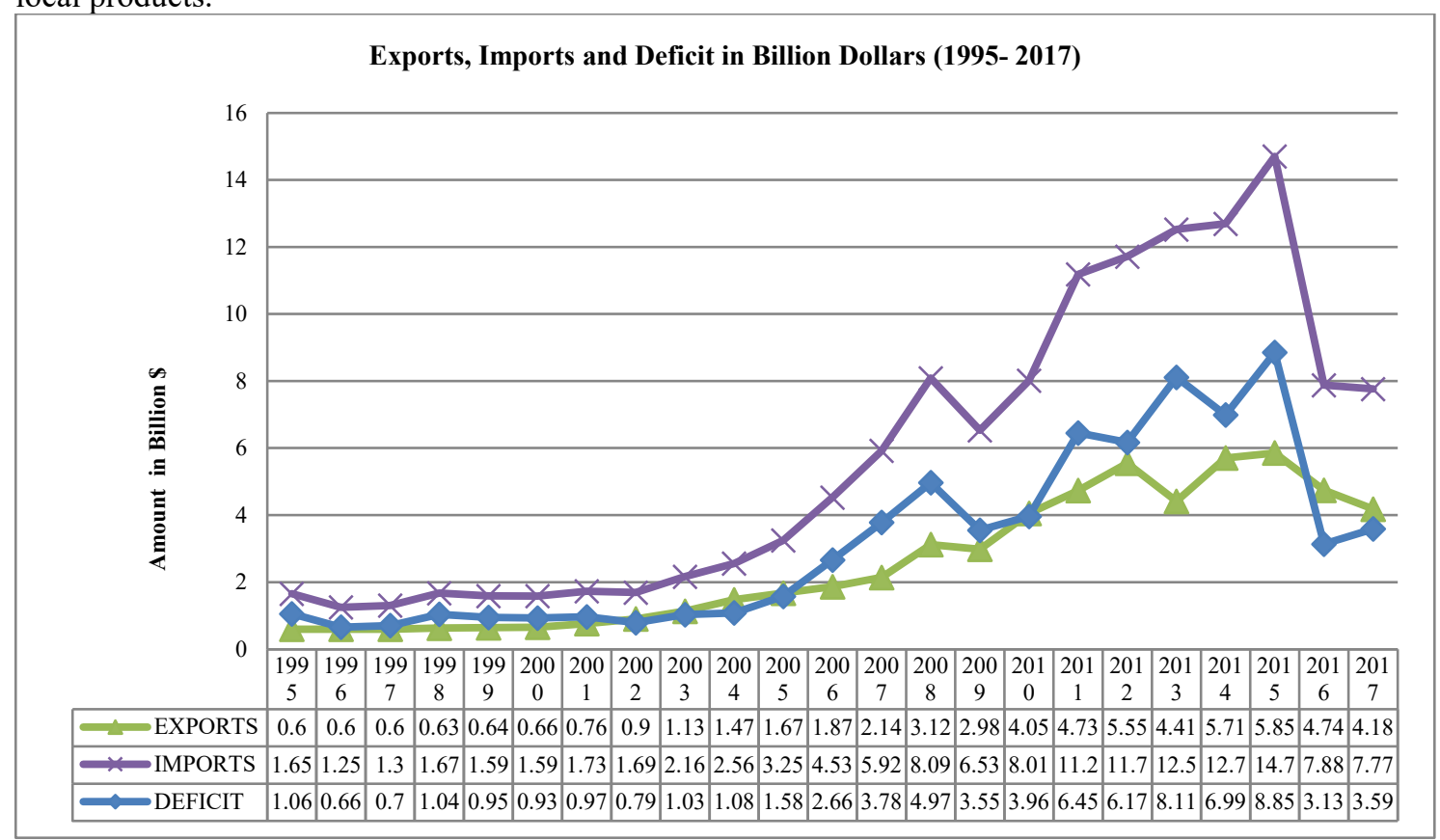

Figure 2.1: Exports, Imports and Deficit in Billion Dollars (1995- 2017)

Source: WITS (2018); Graph made by Author

It has been observed from literature review that GDP in dollar value has been increasing as a result of other GDP factors because the balance of trade has been in deficit balance for 23 since 1995 to 2017 . Likewise, from 2015 to 2016 imports dropped by $46 \%$ and remained steady in 2017 resulting to decrease in trade deficit as export remained steady during the two years 2016 and 2017. The GDP value increased from 47.388 dollars to 52.09 dollars in 2017. Moreover, Tanzania has shown great initiative strategies by embarking on industrialized economy in many sectors like the aviation, maritime, tourism, railways, roadways, human resource development and in budgeting. The economy of Tanzania is expected to revamp from where it was to a sustainable one. In this regard and according to data set the phenomena on the dynamic relationship of GDP, Exports and Imports and their causality in Tanzania is little known as they are little or no studies that have been done in regard of the Dynamic Relationships between Balance of Trade and Economic growth in Tanzania. Therefore, the GDP model is likely to bring that awareness and broaden the understanding of policy and decision makers, community and other stakeholders.

\subsection{Research Methodology}

This study analysed the normalized transformed function GDPT $=\mathrm{f}($ Export, Imports). The Box-Cox linearity plot was used for normalization as it provides convenient way to find a suitable transformation without engaging in a lot of trials and error fittings (Osborn, 2010 and Viélez et al, 2015). The Box-Cox transformation gives the values of $\theta$ and $\lambda$ from which the suitable multiplier(s) for left hand, right hand or both sides can be considered after having satisfied the four statistical conditions. Only the left hand was transformed using $\theta=0.490042 !$. This study has three variables from which the system of three equations was developed. Likewise, the system was tested to examine existence of unit root and performed the bound test to help decide for VECM Model and or ARDL Model. If the variables in the system of three equations are cointegrated then VECM and or ARDL models can be applied; and if any equation in the system is stationary at either $\mathrm{I}(0)$ or $\mathrm{I}(1)$ or the combination of $\mathrm{I}(0)$ and $\mathrm{I}(1)$ then ARDL can be applied. In this study the ARDL model was selected because the system has a combination of both I(1) and I(0). The numbers of lags suiting the statistical conditions for each model were selected. The identified ARDL model was regressed and analysed for long run, short run and causality relationships. 


\subsection{The GDPT Model Equations}

This study analysed the long run and short run relationship between the responded variable Gross Domestic Product (GDP) and the explanatory variables Export and imports. The hypothesis is 'the existence of relationships implies that the macroeconomic policies have effect on the GDP' which mean that international trade policies on exports and imports have significant effect on the economic growth of Tanzania. One of the great advantages of ARDL technique is that, it can be used for regression modelling and analysis of both the long run and short run causal relationships. The long run and short run dynamics relationship is derived through Error Correction Model (ECM) where unrestricted Error correction Term (ECT) was employed. The ECT model was capable of modelling the time series both in the long run and short run. The model can be converging or diverging from the equilibrium, similarly the model can be significant which is desirable or not significant which is undesirable. The point to note here is under the ECM processes the insignificant model may have meaningful and useful information in terms of relationships and causal effects in that time series data set. Keele and DeBoef (2004) stipulating on the dynamics theory made emphasis on considering the theoretical advantage of ECM processes rather than only focusing on statistical characteristics. In time series data a random shock on a predictor variable may cause dynamics effects on the responded variable which can be contemporaneous, equilibrium or both. With temporal data, there three possible dynamics effects which include:-

i. the predictor variable may have only contemporaneous effects to the respondent variable where the effects is immediately but does not persist into the future;

ii. the predictor variable may have contemporaneous effect as well as an equilibrium component that persists across future time periods and decaying at some rate; and

iii. the predictor variable may have no contemporaneous effects but instead have an equilibrium effect where the causal on the respondent only occurs across future time points.

The general forms of equations were presented as follows:-

\subsubsection{The GDPT Regression Model}

$\mathrm{GDPT}_{\mathrm{t}}=\beta_{0}+\sum_{\mathrm{i}=1}^{\mathrm{p}} \beta_{1 \mathrm{i}} \mathrm{GDPT}_{\mathrm{t}-\mathrm{i}}+\sum_{\mathrm{i}=1}^{\mathrm{q}} \beta_{2 \mathrm{i}}$ Exports $_{\mathrm{t}-\mathrm{i}}+\sum_{\mathrm{i}=1}^{\mathrm{r}} \beta_{3 \mathrm{i}} \operatorname{Imports}_{\mathrm{t}-\mathrm{i}}+\varepsilon_{1 t}$

Where, $\mathrm{p}, \mathrm{q}$ and $\mathrm{r}$ represent different lags; $\beta_{1 \mathrm{i}-3 \mathrm{i}}, \alpha_{1 \mathrm{i}-3 \mathrm{i}}$ and $\mu_{1 \mathrm{i}-3 \mathrm{i}}$ are short run coefficients and $\varepsilon_{1 t-3 t}$ are residuals (stochastic error term).

\subsubsection{The Error Correction Model (ECM)}

The equation has three variables which are GDPT, Exports and Imports. The variables were stationary at level and after first difference denoted as $\triangle$ GDPT,$\Delta$ Exports and $\Delta$ Imports. The long run, short run and causal relationships were tested using equation of the form:-

$$
\Delta \mathrm{GDPT}_{\mathrm{t}}=\beta_{0}+\sum_{\mathrm{i}=1}^{\mathrm{p}} \beta_{1 \mathrm{i}} \Delta \mathrm{GDPT}_{\mathrm{t}-\mathrm{i}}+\sum_{\mathrm{i}=1}^{\mathrm{q}} \beta_{2 \mathrm{i}} \Delta \text { Exports }_{\mathrm{t}-\mathrm{i}}+\sum_{\mathrm{i}=1}^{\mathrm{r}} \beta_{3 \mathrm{i}} \Delta \mathrm{Imports}_{\mathrm{t}-\mathrm{i}}+\sigma_{1} \mathrm{ECT}_{\mathrm{t}-\mathrm{i}}+\varepsilon_{1 t}
$$

Where, $\Delta$ is the difference operator; $\mathrm{p}, \mathrm{q}$ and $\mathrm{r}$ represent different lags; $\beta_{1 \mathrm{i}-3 \mathrm{i}}, \alpha_{1 \mathrm{i}-3 \mathrm{i}}$ and $\mu_{1 \mathrm{i}-3 \mathrm{i}}$ are short run coefficients; $\sigma_{i}$ the speed of adjustment, if has negative sign the model converges in a long run and if has positive sign it diverges; $\mathrm{ECT}_{\mathrm{t}-\mathrm{i}}$ is the Unrestricted Error Correction Term (ECT) derived from the long run relationship and $\varepsilon_{1 t-3 t}$ are residuals (stochastic error term).

\subsection{Model testing and Stability}

The ARDL Model for the system of equation GDPT, model, Exports Model and Imports Model were examined for unit root test, bound test, lags selections and satisfactions of the statistical conditions. The conditions include normality, no heteroscedasticity, no serial correlation and no white noise. The GDPT model in this study was tested for its structural stability under cumulative residuals (CUSUM), cumulative sum of squares recursive residuals (CUSUMSQ) and Ghansen test; and the model was found satisfactory in regard of all statistical conditions.

\subsubsection{The Unit Root Test}

The test for unit root is essential because most macroeconomic series have unit root (non-stationary characteristics) affecting the macroeconomic policies. The unit root test was used to find whether the individual variables for the GDPT model are stationary at level or after differencing at I(d) levels. Table 4.4 shows that the test-statistic for GDPT (0.041), Export (-0.8300 and Imports (-1.132) were greater than 5\% critical value $=-3$ of the interpolated Dickey-Fuller confirmed by the MacKinon approximate respectively. More over the p-value for the three variables were greater than 0.05 alpha level; so can reject the null hypothesis that variables are unit root. Therefore all the 
variables are stationary at level.

Table 4.5: Augmented Dickey-Fuller test for unit root

\begin{tabular}{|l|c|c|c|c|}
\hline Variable & Test Statistics & 5\% Critical Value & P-value for z(t) & I(d) \\
\hline GDPT & 0.041 & -3.000 & 0.9618 & $\mathrm{I}(0)$ \\
\hline Exports & -0.830 & -3.000 & 0.8103 & $\mathrm{I}(0)$ \\
\hline Imports & -1.132 & -3.000 & 0.7020 & $\mathrm{I}(0)$ \\
\hline
\end{tabular}

Sources: Stata Output

3.2.2 The bounds Test

The bounds test for the three endogenous variables GDPT, Exports and Imports was carried in order to specify whether to use the VECM and or ARDL. The variables at first differences are denoted $\Delta \mathrm{GDPT}, \Delta$ Exports and $\Delta$ Imports. If the results for the bounds test shows that $\mathrm{F}>$ critical value for I(1) regressors reject $\mathrm{H}_{0}$ : no level relationship, by rejecting $\mathrm{H}_{0}$ : it implies that variables have relationship at levels and are cointegrated of order one. Similarly, if $\mathrm{t}>$ critical value for $\mathrm{I}(0)$ regressors, accepted $\mathrm{H}_{0}$ : no level relationship which implies that variables have no relationship at levels and are not cointegrated. Either where F-statistics falls between the bounds, the test is inconclusive. The bound test results for the GDPT Model showed $\mathrm{F}(0.051)>(-$ $0.156)$ which is $\mathrm{I}(0)$, For Exports Model showed $\mathrm{F}(7.059)>(-4.570)$ which is $\mathrm{I}(1)$ and for Imports Model showed $\mathrm{F}(7.594)>(-4.623)$. The bound test showed that the system of three equations are stationary at levels of I (0) and first difference at level I (1) orders of integrations meaning that the model is integrated of different orders I(0) and $\mathrm{I}(1)$. According to Nkoro and Uko (2016), when the time series is a combination of $\mathrm{I}(0)$ and $\mathrm{I}(1)$ and the sample size $\mathrm{n}<30$ then ARDL model can selected to test their relationships and causal effects in the long run and short run because ARDL is relatively efficient for small sample. The variables in GDPT Model were not cointegrated and the ARDL Model was selected.

\subsubsection{Lags Selection}

The residuals for GDP model was found to be normally distributed, homoscedasticity, no serial correlation and are white noise. The process started by Firstly, selecting the number of lags; the lags were chosen using lag selection criteria. The lags were scrutinised to identify which ARDL (p, q, r) regression meet the statistical conditions. The conditions include normality, no heteroscedasticity, no serial correlation and no white noise. As shown in Table 4.1 the ARDL (1 3 1), ARDL ( $\left.\begin{array}{lll}3 & 4 & 0\end{array}\right)$ and ARDL ( $\left.\begin{array}{lll}4 & 3 & 3\end{array}\right)$ satisfied the statistical conditions and the analysis was made pertaining to the system of these three equations.

Table 4.1: ARDL Regression Model Selection

\begin{tabular}{|l|c|c|c|c|c|c|}
\hline Equation & $\begin{array}{c}\text { Regression } \\
\text { Model Approach }\end{array}$ & Normality & Heteroscedasticity & $\begin{array}{c}\text { No serial } \\
\text { correlation }\end{array}$ & $\begin{array}{c}\text { White } \\
\text { noise }\end{array}$ & $\begin{array}{c}\text { Bound } \\
\text { test }\end{array}$ \\
\hline $\begin{array}{l}\text { GDPT } \\
\text { Model }\end{array}$ & ARDL (1, 3, 1) & 0.05914 & 0.3999 & 0.8320 & 0.5751 & $\mathrm{I}(0)$ \\
\hline $\begin{array}{l}\text { Exports } \\
\text { Model }\end{array}$ & ARDL (3, 4, 0) & 0.85118 & 0.4946 & 0.3812 & 0.3959 & $\mathrm{I}(1)$ \\
\hline $\begin{array}{l}\text { Imports } \\
\text { Model }\end{array}$ & ARDL (4, 3, 3) & 0.59292 & 0.2119 & 0.4136 & 0.3587 & $\mathrm{I}(1)$ \\
\hline
\end{tabular}

Sources: Stata Output

\subsubsection{Stability of GDP Model}

Testing of structural changes in time series is concerned with structural stability from which intercept and structural breaks are exhibited (Baum, 2006). The cumulative sum of recursive residuals (CUSUM) measures stability of regression coefficient changing systematically $\left(\mathrm{H}_{0}=\right.$ coefficients are stable). On the other hand the cumulative sum of squares of recursive residuals (CUSUMSQ) measures structural breaks in volatility of regression coefficient when sudden changes occur $\left(\mathrm{H}_{0}=\right.$ coefficients are volatility). Moreover, the Ghansen test for break point where $\mathrm{H}_{0}$ : no cointegration at break; and if the absolute value $\mathrm{z}(\mathrm{t})>5 \%$ asymptotic critical value then reject $\mathrm{H}_{0}$

The structural stability of GDPT model using CUSUM test in Figure 3.2 showed that the points lie inside the critical bound, this implies that the GDP model is stable. From CUSUM analysis the economic growth of Tanzania has been stable for quite a long time as the movement of the coefficient are stable to explain and predict the movements for the past 23 years. Likewise, the CUSUMSQ test shown no structural breaks and Ghansen test for break point showed that $\mathrm{z}(\mathrm{t})=4.69$ was less than 5.29 at $5 \%$ critical value so cannot reject $\mathrm{H}_{0}$ meaning that the points below the boundary are not cointegrated meaning that have neither effects nor distorted the time series to account them as structural breaks which affects the system model in a long run. Nevertheless, Imimole (2017) pointed out that the model converges it implies that the macroeconomics' policies have been effectively implemented. The GDPT model does not converge in the long run, this mean that economy in Tanzania require to stabilisation and resilient mechanism for it to be capable of adjusting itself when subjected to economic shocks. 


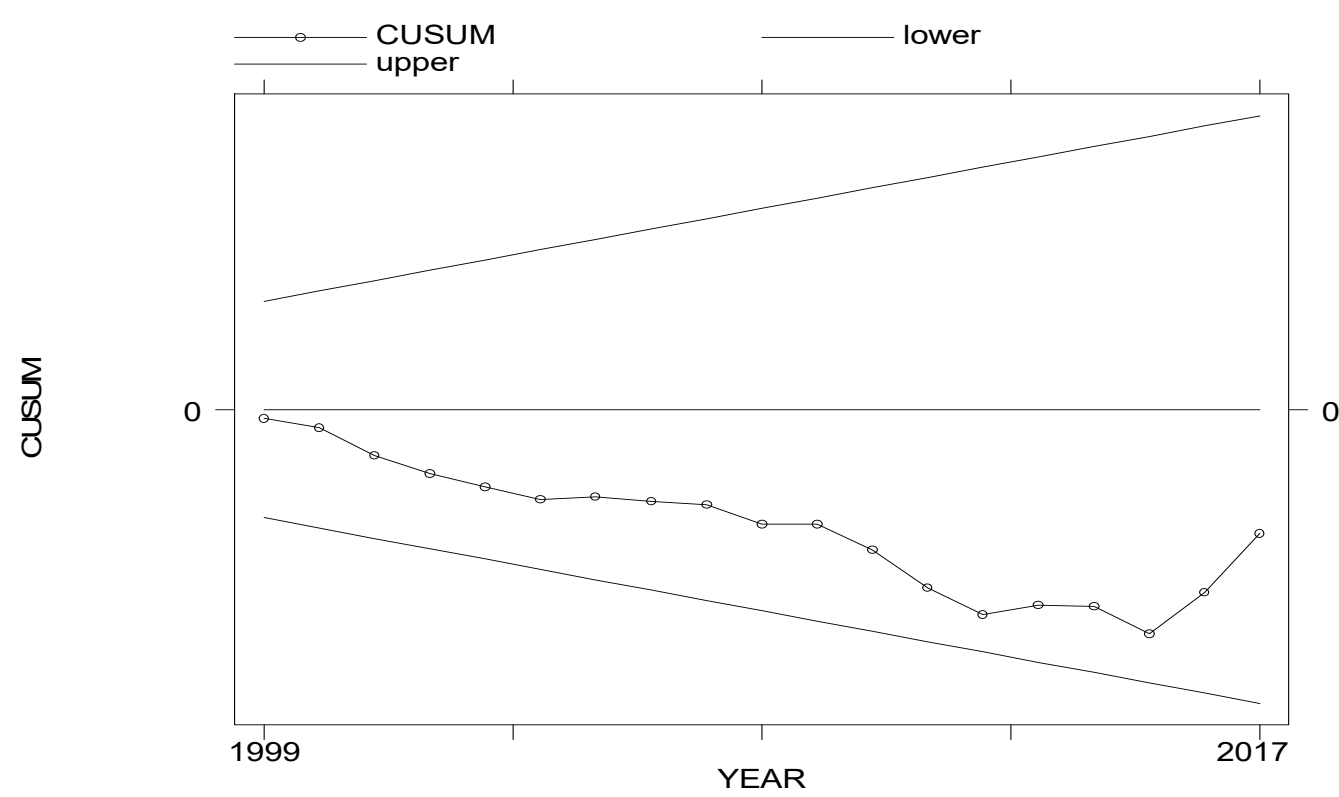

Figure 2. 3: Cumulative Sum of Recursive Residuals

Source: Stata Output

\subsection{Discussion and Findings}

\subsection{The GDPT Model}

The model GDPT model was regressed using the ARDL $(1,3,1)$ techniques approach and the regression model was found the equation to be

$$
\begin{aligned}
\text { GDPT }_{\mathrm{t}}= & 0.215+0.972 \mathrm{GDPT}_{\mathrm{t}-1}-0.0627 \text { Exports }_{\mathrm{t}}+0.0497 \text { Exports }_{\mathrm{t}-1}+0.313 \text { Exports }_{\mathrm{t}-2}- \\
& 0.279 \text { Exports }_{\mathrm{t}-3}+0.068 \text { Imports }_{\mathrm{t}}-0.697 \text { Imports }_{\mathrm{t}-1}
\end{aligned}
$$

It was found from the regression results in Table 4.1 that Prob $>F=0.0000$ is less than 0.05 , so there is some evidence to reject the null hypothesis which says the coefficient of determination $r^{2}=0.9924$ is zero'. So, the argument is made in favour of alternative hypothesis that $\mathrm{r}^{2}$ is not zero and is very high; implying that the model has some explanatory power and is jointly significant. On the other hand, the coefficient of determination $\mathrm{r}^{2}=.9119$ implies that 99.24 percent is explained by Exports and Imports while only 0.76 percent is not explained (Error). For GDPT variable at first lag $(p=0.000)$ it is significant, likewise, for Exports variable for the time $t(p=0.609)$ and the first $\operatorname{lag}(p=0.669)$ it is not significant, moreover for the second lag $(p=0.012)$ and third lag $(p=0.015)$ it is significant. On the other hand for Imports variable for the time $t(p=0.104)$ it is not significant and for the first lag $(\mathrm{p}=0.012)$ it is not significant. The significances levels imply that a change in dollar for first lag of GDPT, results in percentage in $0.9723 \mathrm{GDPT}$ output which imply that this high increase is coming from absorption factor $(\mathrm{C}+\mathrm{I}+\mathrm{G})$. Also the percentage change in dollar for second lag and third lag of exports results in percentage change increase in 0.3130 exports output and decrease in 0.2792 exports output.

\section{Table 4.1: The GDPT Model Regression Output}

\begin{tabular}{|l|c|c|c|}
\hline Variable & Coefficient & t-Statistics & P-value for $\mathbf{z}(\mathbf{t})$ \\
\hline GDPT L1 & 0.9722648 & 5.38 & 0.000 \\
\hline Exports -- & 0.0627123 & -0.53 & 0.609 \\
\hline Exports L1 & 0.0496505 & 0.44 & 0.669 \\
\hline Exports L2 & 0.3129578 & 2.94 & 0.012 \\
\hline Exports L3 & -0.279241 & -2.82 & 0.015 \\
\hline Imports -- & 0.0680032 & 1.76 & 0.093 \\
\hline Imports L1 & -0.0696603 & 1.76 & 0.658 \\
\hline Constant & 0.2151049 & 0.45 & \\
\hline
\end{tabular}

Sources: Stata Output

\subsection{The Error Correction Model (ECM)}

The ECM Model output as shown in Table 4.2 indicates that the coefficient of the adjustment (ADJ) coefficient is not significant which mean that there is no causal effects implication of Exports and Imports over GDPT in a long run. Likewise, Exports and Imports are insignificantly having no causal effects to GDPT model in the long run. On the other hand only Exports is significant and affects GDPT positively in a short run while Imports is 
insignificant over GDPT in a short run. The GDPT- ECM model equation written as

$$
\begin{aligned}
\Delta \mathrm{GDPT}_{\mathrm{t}}= & 0.2151-0.0834 \Delta \text { Exports }_{\mathrm{t}-1}-0.03372 \Delta \text { Exports }_{\mathrm{t}-2}+0.2792 \Delta \text { Exports }_{\mathrm{t}-3}+ \\
& 0.0697 \Delta \text { Imports }_{\mathrm{t}-1}-0.0277 \mathrm{ECT}_{\mathrm{t}}
\end{aligned}
$$

Reading from the model it was found that The GDPT Model has the coefficient of adjustment (ADJ) or Error Correction term (ECT) not significant meaning that the model is not cointegrated, not converging in long run equilibrium and has no causal effects on GDPT. Also, Exports and Imports were insignificantly having causal relationship on GDPT in the long run. However, one good sign is that, the coefficient sign of ECT is negative which mean that the model in case of random shocks is capable of returning towards its equilibrium in the long run. According to Hossain and Abedin (2016) the higher ECT $(-1<\mathrm{ECT}<0)$ indicates a faster return to equilibrium after having shocks from the previous year. For ECT $=-1$ it adjusts at 100 percent being full converges process towards the equilibrium which is 1 year in case annual data set used. The result implies that the $1 \%$ shock to equilibrium will lead to 2.77 percent correction towards equilibrium in the current year after having distorted in the previous year. On the other hand, Exports is significantly having causal relationship in the short run while Imports is insignificant in the short run. That is a 1 percentage change in random shock to equilibrium will lead to increase by 27.92 percent in exports output which is desirable in the short run because Exports is significant. Likewise, 1 percentage change or increase in random shock to equilibrium will lead to increase by 6.97 percent in imports output which is not desirable.

Table 4.2: GDPT - ECM Model Output

\begin{tabular}{|l|c|c|c|}
\hline Variable & Coefficient & t-Statistics & P-value for $\mathbf{z ( t )}$ \\
\hline ADJ -GDPT L1 & -0.0277352 & -0.15 & 0.881 \\
\hline LR-Exports & 0.7447233 & 0.17 & 0.864 \\
\hline LR-Imports & -0.0597483 & -0.03 & 0.976 \\
\hline SR -Exports D1 & -0.0833673 & -0.64 & 0.532 \\
\hline SR- Exports LD & -0.0337168 & -0.35 & 0.733 \\
\hline SR- Exports L2D & 0.279241 & 2.82 & 0.015 \\
\hline SR -Imports D1 & 0.0696603 & 1.82 & 0.093 \\
\hline Constant & 0.2151049 & 0.45 & 0.658 \\
\hline
\end{tabular}

Sources: Stata Output

\subsection{The Exports and Imports Models}

The other two models which are Exports and Imports models were regressed; Exports as responded variable and Imports as a responded variable. It was found that the Exports model has ADJ= -2.198146 and was significant. The Exports Model has long run causal effects on Imports and GDPT. Only Imports has both long run and short run effects to Exports while GDPT was insignificant over Exports both in the long run and short run. The speed of converges is very high and would take 6 months to adjust to equilibrium in the current year when shocks occurs. Similarly, Imports model has ADJ $=-2.425437$ and was significant. The Imports Model has long run causal effects on Imports and GDPT. Only Imports has both long run and short run effects to Exports while GDPT was insignificant over Imports both in the long run and short run. The speed of converges is very high and would take 5 months to adjust to equilibrium in the current year when shocks occurs.

\subsection{Causality Analysis of factors affecting GDP Model}

For the GDPT model to be cointegrated and converge to equilibrium in a long run the coefficient of ECT must negative and significant. The GDPT model has negative sign coefficient $(-0.0277)$ of the error correction term (ECT) but is not significant. This does not mean that the model is meaningless; the negative sign implies that the model after deviation is capable of returning towards equilibrium in the long run. The correction from deviation normally is expected to happen in the current year having deviated from the previous year. According to Keele and DeBoef (2004) predictors may have contemporaneous effect as well as an equilibrium component that persists across future time periods and decaying at some rate. In this study the GDPT Model is capable of returning to equilibrium in the long run that mean that the predictors Exports and Imports at the speed of 2.77 percent in a year is very small and that reason the GDPT Model will converge in 36 years' time. The insignificant case implies that the explanatory variables Exports and Imports are weak enabler to cause a desirable speed that can bring the economic growth of Tanzania to equilibrium in the current year after having random shocks in the previous year. The trend depicts that, imports have been higher than exports in order to subsidise the consumption gap not available in local markets and very little Imports were geared for boosting local production industries hence in the long run resulting consecutively annual trade deficit balance amounting to 23 years of deficit balance in regard of 
the data set used.

The Exports and Imports as predictors of the GDPT model were insignificant in the long run. Only the Exports variable was significant and contributed 27.92 to GDPT in the short run which is desirable. On the other hand Imports variable in relation to GDPT was insignificant which was also desirable because the imports variable is not directly related to GDPT. The GDPT model equation counts for domestic production output whose factors are personal consumption expenditure (C), gross private domestic investment (I), Government consumption expenditure (G) and Exports (X). According to Lemieux (2017), the Imports (M) is an aggregate value of individual imports let say $\mathrm{m} 1+\mathrm{m} 2+\mathrm{m} 3$ which are embedded in $\mathrm{C}, \mathrm{I}$ and $\mathrm{G}$ respectively and must be subtracted from them immediately. Imports in the GDPT model is represented under the factor (X-M) on the right hand side of the equation and it is negative. Therefore GDPT $=\mathrm{C}+\mathrm{I}+\mathrm{G}+(\mathrm{X}-\mathrm{M})$, and for that matter the relationship between Imports and GDPT is more mathematical than what can be inferred to or from.

Moreover, the two variables Imports and Exports have bidirectional causal relationship both long run and short run, and are capable of converging in the current year. However, the long run deficit shows that the local productions had been not able to suffice the internal consumptions, the phenomena addresses the need for analysis to know if it is due to comparative advantages reasons or bottlenecks in macroeconomic policies. According to Sahoo et al (2016) imports can increase to meet the needs of local export industries and domestic consumers. Tanzania is geared to be an industrial Economy liking economic development and Tanzanian standard of living for that matter it is should import more to facilitate and improve the local production form which can increase Exports and reduce imports supply to domestic consumers in the long run.. According to Ali (2003) discussing the role of imports said that, imports particularly of law materials, capital goods, machinery and modern technology can improve the local production, transportation and other economic sectors which in a long a run boosts exports and economic growth of a country. Tanzania is geared to be an industrialized country in which small and medium industries are likely to dominate in a short run. Hossain and Abedin (2016) points out the importance of government to formulate strategic polices for domestics investments, research and developments expenditure, reduce foreign aid, foreign direct Investment (FDI) and curbing inflations in the short run and long run. The industries are likely to increase local production which greatly shall reduce dependence from foreign products.

It is advisable to promote the provision of policies for demand both the Export-Led Growth (ELG) and Domestic-Led Growth (DLG) approaches to ensure sustainability of the National economic growth. The theory recommends the use of ELG and DLG for sustainable economy; one example is the Japanese Government which applies both ELG and DLG and has sustainable and high economic growth (Sağlam and Egeli, 2017). It is envisaged by this study that the Government of Tanzania through strategic policies on ELG and DLG mixed approaches through research and development can identify International markets in which only products with comparative advantages can be exported. Similarly, Imports that have great impact on industrialization aiming to boost the local production for international and National markets can allowed. Research will help the national to avoid the overdependence on foreign export demand-led growth which in a long run may not be sustainable due aggressive competition in International markets and price. Palley $(2011,2002)$ emphasized that the importance of exports as many countries lack the large enough domestic markets to sustain self-sufficient. However, the domestic development must not be sacrificed for the sake of International Competitive advantages. The ELD era is phasing as in past were applied by few developed countries while as of now all want to apply it making a zero sum dimension. That being the case the DLG model needs to be given its pace regardless of being developed or an emerging market. The DLG require considering the micro and macroeconomic policies in terms of trade liberalization, export demand-led growth, Domestic demand-led growth, financial market liberalization, financial capital mobility, fiscal and monetary austerity, privatization and labor market flexibility.

\subsection{Conclusion and Recommendations}

This was a descriptive Empirical Analysis on the dynamic relationships between balance of trade and economic growth in Tanzania. The variables were Gross Domestic Product (GDPT) as a responded variable and the explanatory variables being Exports and Imports. The GDPT model developed after transforming the variables to obtain the GDPT regression equation and the unrestricted vector error Correction model (ECM) equation.

\subsection{Conclusion}

Using the ARDL technique for analysing GDPT model, it was found that the GDPT model has coefficient with negative sign implying that the variables in the model have relationships; despite of it not being significant which imply no causal effects in the long run. The reasons were that Exports and Imports were weaker enabler having no effects in the long run despite of the short run effects from Exports which did not endure in the long run. The analysis shows that, the predictors' weaknesses were implied by the lower speed of adjustment of 2.77 requiring 36 years to converge to long run equilibrium. Normally, the ECM model estimates the convergence in current year; the speed of the model is low and cannot restore the economic equilibrium in the current after having shocks in the previous year. 
The predictor Exports was significant and has causal relationships on the GDPT variable in the short run. A change in one dollar Exports will lead to increase in 27.92 dollar on GDPT in the short run. On the other hand the Imports variable was not significant in the short run. However, the Imports variable is positive meaning that a change in one dollar insignificantly leads to increase in 6.97 dollar on GDPT something not desirable.

Therefore, the analysis for the dynamic relationship behaviour of the GDPT model shows that macroeconomic policies had been little influencing the international trade of which the long run trade deficit implication have spill over effects on interest rate, FDI, currency, employments specifically and in general the economic growth of Tanzania in this regard. The study found that imports can support booting the growth of local industrialization which in the long run can support the economic growth through ELG and DLG. This was observed from the Exports and Imports models that Exports and Imports forces can adjust to equilibrium in the current year when shocks occurs in the previous year. Nevertheless, Tanzania of recent has embarked on industrialized economy which is essential for any development change and sustainability.

\subsection{Recommendations}

The study recommends that International trade should be keenly and prudently managed by having strategic polices. Also, research and development should be made to strategically identify what to be imported and exported, where, to whom, how much and its comparative advantage. Likewise, the study on consequences of all factors constituting to GDP should be made. Moreover, there should be kind of strategic promotions and motivations to local producers to use more local materials and domestic consumers to use products available in local markets to maximise their needs.

Note: any leader of this research is reminded that the conclusion made in regard of this study is based on historical time series data set and statistical inferences. However, the results and statistical inference made may indeed be of interest and useful to policy and decision makers, the community and researchers.

\section{REFERENCES}

Ali, S. (2013). Cointegration Analysis of Exports and Imports: the Case of Pakistan Economy. The European Journal of Technology and Development, (11) 32-38

Al-Khulaifi, A.S.(2013).Exports and Imports in Qatar: Evidence From Cointegration and Error Correction Model. Asian Economic and Financial Review 3(9):1122-1133.

Bakari, S. and Krit, M. (2017). The Nexus between Exports, Imports and Economic Growth: Evidence from Mauritania. International Journal of Economic and Empirical Research 5(1): 10-17.

Baum, C.F. (2006), An Introduction to Modern Econometrics Using Stata. A Stata Press Publication. StataCorp LP. USA.

Felipe, J and Lim, J (2005). Export or Domestic - Led Growth in Asia? ERD working Paper No. 69: 1-51, Economics and Research Department, Asian Development Bank, Manila Philippines.

Hossain, S. and Abedin, T. (2016). Multivariate Dynamic Co-integration and Causality Analysis between Inflation and its Determinants. Journal of Economics and Behavioral Studies 8(5)240-250.

Imimole, B.(2017).Testing for Sustainability of Current Account Deficit in Nigeria. Journal of Economics and Sustainable Development 15(8):1-7.

Keele, L. and DeBoef, S. (2004). Not Just for Cointegration: Error Correction Models with Stationary Data. [Online] Available: https://www.nuff.ox.ac.uk/politics/papers/2005/Keele\%20DeBoef\%20ECM200441213.pdf (February 17, 2019)

Nkoro, E. and Uko, A.K. (2016). Autoregressive Distributed Lag (ARDL) Cointegration technique: application and interpretation. Journal of Statistical and Econometric Methods 5(4) 63-91.

Palley, T.I (2002). A new Development Paradigm Domestic Demand-Led Growth. Why it is need and How to make it Happen. A revised version of a paper presented at the Alternatives to Neoliberalism Conference. Washington, DC.

Palley, T.I (2001). The Rise and Fall of Export - Led Growth. Levy Economics Institute, Working Paper N0. 675. [Online] Available: https://www.levyinstitute.org (February, 15, 2019).

Romero Jessie (2017). Balance of Trade. Jargon Alert. [Online] Available: Region Focus | Second/Third Quarter 2012. https://www.richmondfed.org/-/media/Richmondfedorg/publications/research/econ_focus/2012/q23/pdf/jargon_alert.pdf (November 29, 2018).

Sağlam, Y. and Egeli, E. (2017). Emperical Analysis of Export -Led Growth and Domestic-Led Growth Hypotheses in East Asia. International Journal of Economics and Administratives Studies (19): 211 - 226.

Sahoo, M., Babu, M.S. and Dash D. (2016). Long run Sustainability of Current Account Balance of China and India: New Evidence from Combined Cointegration Test. Intellectual Economics.(10):7891.[Online]Available: https://www.sciencedirect.com/science/article/pii/S1822801116300261(December 27, 
2018).

The World Bank (2018). Tanzania Gross Domestic Product. [Online] Available:https://data.worldbank.org/country/Tanzania (November 27, 2018).

The World Integrated Trade Solution (2018). Tanzania Exports, Imports and Trade Balance by Country and Region. [Online]

Available: https://wits.worldbank.org/countryProfile/en/Country/TZA/Year/2016/TradeFlow/EXPIMP (November 29, 2018).

Zestos and Michelis (2004). Exports, Imports and GDP Growth: Causal Relations in Six European Union Countries. Journal of Economic Asymmetries 1(2):71-85 